\title{
Risk Factor About Stunting Among Toddlers Aged 24-59 Months in Sabang City
}

\author{
${ }^{1}$ Ramadhaniah, ${ }^{1}$ Adityo Sendi, ${ }^{1}$ Azwar Eddy, ${ }^{2}$ Teuku Muliadi \\ ${ }^{1}$ Faculty of Public Health, Universitas Muhammadiyah, Aceh, Indonesia \\ ${ }^{2}$ Nutrition Department, Faculty of Public Health, Universitas Teuku Umar, Aceh, Indonesia \\ Coresponding author: Ramadhaniah, e-mail: Ramadhaniah@gmail.com \\ Co-author: AS: sendiadityo@gmail.com, AE: eddyazwar@gmail.com, TM: teukumuliadi@utu.ac.id \\ Submitted:31/03/2021 Revised:08/04/2021 Accepted:09/04/2021 Published online: 14/04/2021
}

doi: https://doi.org/10.35308/j-kesmas.v7i2.1646. How to cite this article: Rahmadaniah., Sendi, S., Eddy, A \& Muliadi, T. (2021). Risk Factor About Stunting Among Toddlers Aged 24-59 Months in Sabang City. J-Kesmas: Jurnal Fakultas Kesehatan Masyarakat (The Indonesian Journal of Public Health).8(1): 25-29.

\begin{abstract}
Stunting is a difficult problem faced by all countries today. Data shows that in 2017 the stunting rate reached 22.2\%, or about 150.8 million toddlers experienced stunting. In this study, we used a crossectional research design with a total sample of 1489 people. Our results showed $61.9 \%$ of toddlers suffered from stunting, $69.8 \%$ of respondents with good health care patterns, $74.6 \%$ of respondents who had a history of infectious diseases in the existing category, $58.7 \%$ of respondents with NLHB in the poor category, and $74.6 \%$. The category of respondents to the information media that ever existed. those at risk of stunting are health patterns ( $p$-value $=0.017)$, history of infectious diseases (value $p=0.020)$ and NLHB $($ value $p=0.031)$.
\end{abstract}

Keywords: Stunting; Parenting Style; NLHB (Net Living Health and Behaviour); Infectious Disease; information media

\section{Introduction}

Stunting is global problems causes nutritional deficiency. An imbalance causes stunting in the diet. In 2017, there were 150.8 million cases of stunting found in the world. Data shows that in 2017 the stunting rate reached $22.2 \%$, or about 150.8 million toddlers experienced stunting This result indicates a big stunting problem in the Southeast Asia region, especially Indonesia (Pusdatin, 2018). Linear height growth is considered the best indicator of child health for measuring imbalances in growth and development. (Ministry of Health, 2016). Based on the initial survey, it was found that the incidence of stunting in PUSKESMAS Sukakarya was due to the lack of public awareness about stunting (Dinkes Sabang, 2019). According to Ni'mah khoirun, et al. (2015), risk factors associated to stunting events are birth length, malnutrition, history of infectious diseases, family income, maternal education, and nutritional intake knowledge. But there needs to be an integrated and multisectoral program to tackle stunting in toddlers.

According to Solin Angina Rohdalya et al., (2019), the history of infectious diseases shows that toddlers' age characteristics are 12-36 months, as much as $76.4 \%$. The study results of the incidence of diarrhea and stunting showed results that as much as (93.3\%) who often experience diarrhea and stunting. In comparison, those who often experience ISPA with stunting $(83.3 \%)$.

According to Ni'mah khoirun et al., (2015), risk factors related to stunting events are birth length, malnutrition, infectious diseases, family income, maternal education, and nutritional intake knowledge. But there needs to be an integrated and multisectoral program to tackle stunting in toddlers. According to Solin Angina Rohdalya et al., (2019), the history of infectious diseases shows that toddlers' age characteristics are 12-36 months, as much as $76.4 \%$. Diarrhea and stunting (93.3\%) ARI and Stunting $(83.3 \%)$. Suggests that a history of infectious diseases is one of the factors related with growth in toddlers.

\section{Methods}

This study is a type of descriptive-analytical research, dependent variables, and independently researched simultaneously at the time of the study. Researcher chose the Cross-sectional design because the faster it delivers results, fewer research subjects, and can be used to identify various risk factors at once in a single study. 
The population is the entire subject of research (Arikunto, 2014). We used all toddlers stunting and not stunting in were sample at the PUSKESMAS. Sukakarya, as many as 149 people were collected. Samples represent a population taken through specific means with certain, clear, and complete characteristics considered to represent the population (Arikunto, 2014). The sample in this study was a small part of the total number of toddlers who have 24-59 months, which is as many as 63 people.

\section{Results}

Tabel 1. Respondent Frequency Distribution based on Respondent

\begin{tabular}{lcc}
\hline \multicolumn{1}{c}{ Characteristic } & Frequency & $\begin{array}{c}\text { Percentage } \\
(\%)\end{array}$ \\
\hline Stunting & 24 & 38,1 \\
Yes & 39 & 61,9 \\
No & & \\
Health Care Pattern & 44 & 69,8 \\
Good & 19 & 30,2 \\
Not good & & \\
Infectious Disease & 47 & 74,6 \\
Yes & 16 & 25,4 \\
No & & \\
NLHB & 26 & 41,3 \\
Good & 37 & 58,7 \\
Not Good & & \\
Information Media & 47 & 74,6 \\
Received & 16 & 25,4 \\
No Received & \\
\hline
\end{tabular}

Source : Primary Data (Processed in 2020)

The univariate analysis results above, namely the number of samples with stunting nutritional status of $38.1 \%$ and models with the regular dietary rate of $61.9 \%$. The example was mainly with a good health care pattern of $69.8 \%$, and there was a history of infectious diseases of $74.6 \%$. The sample that did NLHB well was $41.3 \%$, and the selection that had been informed stunting through the media was $74.6 \%$.

The analysis consists of health care patterns, infectious disease history, NLHB, and information media. In this study, the statistical test used is the chisquare test, follow table 2. below :

Tabel 2. Bivariate Anaysis

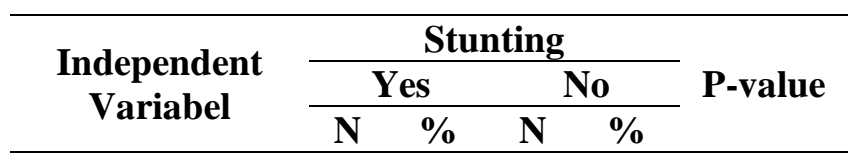

\begin{tabular}{|c|c|c|c|c|c|}
\hline \multicolumn{6}{|c|}{ Health Care Pattern } \\
\hline Good & 21 & 47,7 & 23 & 52,3 & \multirow{2}{*}{0,017} \\
\hline Not Good & 3 & 15,8 & 16 & 84,2 & \\
\hline \multicolumn{6}{|c|}{ Infectious Disease } \\
\hline Yes & 14 & 29,8 & 33 & 70,2 & \multirow{2}{*}{0,020} \\
\hline No & 10 & 62,5 & 6 & 37,5 & \\
\hline \multicolumn{6}{|l|}{ NLHB } \\
\hline Yes & 14 & 53,8 & 12 & 46,2 & \multirow{2}{*}{0,031} \\
\hline No & 10 & 27,0 & 27 & 73,0 & \\
\hline \multicolumn{6}{|c|}{ Information Media } \\
\hline Receive & 17 & 36,2 & 30 & 63,8 & \multirow{2}{*}{0,950} \\
\hline No Receive & 7 & 43,8 & 9 & 56,2 & \\
\hline
\end{tabular}

Source : Primary Data (Processed in 2020)

The result of this study showed that good category parenting patterns as much as $52.3 \%$, more significant than toddlers who did not share stunting (average) with a good parenting pattern of only $47.7 \%$. While toddlers experienced stunting with poor parenting patterns as much as $84.2 \%$, more significant than toddlers who did not share stunting (standard) with a less good category foster pattern of only $15.8 \%$. Chi-square test result obtained a p-value value of 0.017 .

The result of this study the percentage of toddlers who experienced stunting with a history of infectious diseases category. There is much as $70.2 \%$, more significant than toddlers who did not share stunting (standard), only 29.8\%. Simultaneously, toddlers who did not experience stunting (typical) with a history of infectious diseases were not as much as $62.5 \%$ greater than toddlers who participated in stunting, only $37.5 \%$. The p-value obtained after analysis was 0.020 .

The result of this study the percentage of toddlers who did not experience stunting (typical) with NLHB good category as much as $53.8 \%$, more significant than toddlers who participated checking only $46.2 \%$. In contrast, toddlers experienced stunting $73.0 \%$, more potent than toddlers who did not share stunting (standard), only 27.0\%. Statistical test result obtained a p-value value of 0.020 .

Percentage of toddlers who experienced stunting with category information media ever as much as $63.8 \%$, more significant than toddlers who did not share stunting (normal) only $36.2 \%$. In contrast, toddlers who experienced stunting with information media were never as much as $56.2 \%$, more significant than toddlers who did not share stunting (standard), only $43.8 \%$. Chi-square test results with p-value of 0.590 . 
Tabel 2. Multivariate Anaysis

\begin{tabular}{lccc}
\hline Indepent Variable & $\begin{array}{c}\boldsymbol{P} \\
\text { value }\end{array}$ & OR & $\mathbf{9 5 \%} \mathbf{C I}$ \\
\hline $\begin{array}{l}\text { Health Care } \\
\text { Pattern }\end{array}$ & 0,023 & 4,870 & $1,240-$ \\
Infectious Disease & 0,024 & 0,255 & $0,077-$ \\
& & & 0,836
\end{tabular}

Source : Primary Data (Processed in 2020)

After being issued gradually, a variable with a significant p-value (lowest p-value) is obtained as a model candidate, namely health care patterns and a history of infectious diseases. Based on the multivariate analysis table above known, the double logistic regression test's final model states the variables associated meaningfully with stunting events are foster health patterns. The variable of health foster patterns obtained or value $(\operatorname{Exp} B)=$ 7,693 .

\section{Discussion}

\section{Health Care Pattern}

Our study result showed that health care patterns can causes aged 24-59 months in PUSKESMAS Sukakarya Sabang city in 2020 with p-value $=0.017$. Aramico, et al. (2013) study showed that there is a relationship that the category of poor parenting patterns is at 8.07. In addition, our results also show that stunting can also be caused by low maternal parenting, our analysis shows a p-value of 0.001 . Although there are several studies like that done by this research, however, this research is not in line with Renyoet, Brigitte Sarah et al., (2013), showed that parenting is not related, but their study did not explain the parenting style in question. According to Rachmawati (2005), Parenting is any form and process of interaction between parents and children that can affect the individuality of the child and can interfere with the growth and development of the child. Parental interaction in learning to determine the character of the child later. According to Virdani (2015) usually, children who are well cared for by mothers will have an impact on good nutrition. (Virdani, 2015).

\section{Infectious Disease}

In this study, we found that infectious diseases both caused by diarrhea and ARI can affect the growth of toddlers, as evidenced by our analysis in this study that shows p-value 0.002. According to
Solin, A.R et al., (2019). They study showed the same thing with were study. They found that toddlers who have diarrhea with stunting incidence as much as $93.3 \%$ with the results obtained $\mathrm{P}$ value $(0.000)<$ $(\alpha=0.05)$ states that there is a strong relationship between diarrheal infectious diseases to stunting events in toddlers. But in this section, we differ with Glaudia, P. et al. (2016), which shows the result that there is no correlation between stunting child with diarrhea or (infectious disease). According to them, children who experience stunting can be caused by many factors. Diarrhea or diarrhea that occurs in the child only lasts $1 / 2$ day, so it does not impact stunting. (Gibney, 2016). According to Picauly (2013), children stunting is caused by infectious diseases. Then the condition must occur and last a long time to ascertain and analyze risk factors.

\section{Dominant Factors}

At the end of this section, we will explain that the magnitude of NLHB influence on stunting. We found that people who had unhealthy and unclean lifestyles would have a chance of being inhibited. We also compare with some other pins, as did Munawaroh in 2015. Their results showed that there is a robust correlation between NLHB and independent variables, namely stunting. correlation test relationship product-moment behavior NLHB with nutritional status wight-for-height obtained $\mathrm{p}$-value of 0.030.Schmidt and Charles (2014) stated that the short status (edit) improves nutritional interventions and requires prevention efforts and a life-in-life approach with sanitation and environmental hygiene. One of the factors of Clean and Healthy Living Behavior is the sanitary and ecological hygiene factors.

Based on the chi-square statistical test results, it can be concluded that there is no relationship of information media with stunting incidents in toddlers aged 24-59 months in the working area of the center of gold and Sabang city in 2020 (p-value=0.590). According to researchers, there is no link between the information media and stunting events. Parents who have been informed about stunting can make stunting prevention efforts to reduce the percentage of stunting. On the contrary, parents who never get information about stunting will be less aware of who can prevent stunting, so the number of stunting events increases.

The use of print/visual media produced through mechanical and photographic processes only stimulates the eye's senses (vision). On the other hand, electronics and mechanics can produce optical media by delivering accurate information with both 
sound and vision to provide strength in both hearing and vision (Setiawati, 2018).

In this study we prove from the calculation of logistic regression as our analysis unit of several factors related to short in PUSKESMAS Sukakarya. It is known that the most dominant factor influencing stunting events is the pattern of foster health. The greater the OR of a variable, the more likely these risk factors cause toddlers to experience stunting.

\section{Conclusion}

The conclusions in this study show that there is a link between Health Foster Patterns, History of Infectious Diseases, and NLHB to stunting events conducted in PUSKESMAS Sukakarya Sabang city. Still, there is no connection between the Information Media and stunting events in toddlers aged 24-59 months in the working area. The most influential variable in this study is the Health Foster Pattern

\section{Acknowledgement}

Praise to the Almighty Allah for His guidance and mercy. Thanks to all friends and colleagues who have contributed to this research until it is published. Thanks to Universitas Muhammadiyah Aceh for the research funding assistance.

\section{Author Contribution and Competing Interest}

The first researcher has the largest contribution in this research, starting from the preparation of the proposal to the report of the research results. The second and third writers have contributed in collecting the data, processing and assisting the first writer in completing this article. The author assures that there is no conflict of interest in the activities and preparation of this report.

\section{Publisher's Note}

J-Kesmas: Jurnal Fakultas Kesehatan Masyarakat (Indonesia Journal of Public Health) remains neutral with regard to jurisdictional claims in published institutional affiliation.

\section{References}

Aramico, B., T. Sudargo., \& J. Susilo (2013). Hubungan Sosial Ekonomi, Pola Asuh, Pola Makan dengan Stunting pada Siswa Sekolah Dasar di Kecamatan Lut Tawar, Kabupaten
Aceh Tengah. Jurnal Gizi dan Dietik Indonesia, 1(3): 121-130.

Bappenas. (2018). "Pedoman Pelaksaan Intervensi Penurunan Stunting Di Indonesia".

Beatty, Amanda, et al., (2017). Stunting Prevalence And Correlates Among Children In Indonesia. Mathematica Policy Research. 1-5.

Charles.W \& Schmidt. (2014). Beyond Malnutrition, The Role of Sanitation in Stunted Growth. Environmental Health Perpevtives. 122(11): 298-303.

Dinas Kesehatan Kota Sabang. (2019). Laporan Status Gizi Dinas Kesehatan Kota SabangTahun 2019. Kota Sabang

Glaudia, P.G., Nancy, SH., \& Dina V.R. (2016). Hubungan Antara Riwayat Penyakit Infeksi Dengan Kejadian Stunting Pada Anak Usia 1336 Bulan Di Wilayah Kerja Puskesmas Tuminting Kota Manado.

Kemenkes RI. (2016). Pusat Data dan Informasi tentang situasi balita pendek. Jakarta

Kemenkes Ri. (2013). Riset Kesehatan Dasar (Riskesdas)Tahun 2013. Jakarta: Kementerian Kesehatan RI.

Munawaroh, S. (2015). Pola Asuh Mempengaruhi Status Gizi Balita.Jurnal Keperawatan. 6 (1): 44-50.

Ni'mah, Khoirun et al., (2015). Faktor Yang Berhubungan Dengan Kejadian Stunting Pada Balita". Media Gizi Indonesia. 10(1).

Picauly I \& Toy SM. (2013). Analisis Determinan Dan Pengaruh Stunting Terhadap Prestasi Belajar Anak Sekolah Di Kupang Dan Sumba Timur, NTT. JurnalGizidanPangan. 8 (1) : 55 62.

Pusdatin. (2016). Upaya Interfensi Gizi Spesifik Pada 1000 Hari Pertama Kehidupan.

Puskemas Sukakarya kota sabang. (2019). Laporan Status Gizi puskesmas sukakarya Kota SabangTahun 2019. Kota Sabang.

Renyoet., Brigitte., Drajat., M., \& Dadang, S. (2013). Potensi Kerugian Ekonomi Karena Stunting pada Balita di Indonesia Tahun 2013. Jurnal pangan. 11(3).

Solin, Angina Rohdaly et al., (2019). Hubungan Kejadian Penyakit Infeksi Terhadap Kejadian Stunting Pada Balita 1-4 Tahun. Jom Fkp. 6(1)

Septiani, F. (2015). Analisis Faktor Risiko Kejadian Stunting Pada Anak Balita Di Wilayah Kerja Puskesmas Muara Tiga Kabupaten Pidie. Tesis Fakultas Kesehatan Masyarakat Universitas Sumatera Utara Medan.

Setyawati,V.A.V. (2018). Kajian Stunting Berdasarkan Umur dan Jenis Kelamin di Kota 
Semarang. Jurnal University Research Colloqium.

Virdani. (2015). Hubungan Pola Asuh Terhadap Status Gizi Balita Usia 12-59 Bulan di Wilayah Kerja

Widari. (2018). Hubungan Berat Badan Lahir Rendah dan Penyakit Infeksi dengan Kejadian Stunting
Pada Baduta di Desa Maron Kidul Kecamatan Maron Kabupaten Probolinggo. Amerta Nutr. 373-382.

$* * * * * * * * *$ 